\section{Mullis, Kary Banks}

\author{
A. M Gressner ${ }^{1}$ und O. A Gressner ${ }^{2}$ \\ ${ }^{1}$ Labor Dr. Wisplinghoff Berlin, Berlin, Deutschland \\ ${ }^{2}$ Labor Dr. Wisplinghoff und Kollegen Köln, Köln, \\ Deutschland
}

Lebensdaten US-amerikanischer Biochemiker und Nobelpreisträger, geboren am 28. Dezember 1944 in Lenoir, North Carolina, USA.

Verdienste K. Mullis erhielt 1966 seinen Bachelor in Chemie von dem Georgia Institute of Technology und 1973 den $\mathrm{PhD}$ in Biochemie von der University of California, Berkeley. Nach universitären Forschungstätigkeiten hat Mullis 1979 bei der Cetus Corporation in Emeryville, CA, für 7 Jahre eine Forschungaufgabe übernommen, die sich mit der Oligonukleo- tidsynthese beschäftigte und zur Entwicklung der PolymeraseKettenreaktion führte. 1986 wurde Mullis Direktor einer Firma, die sich mit molekularer DNA-Technologie und Photochemie beschäftigte. Anschließend folgte eine umfangreiche Beratertätigkeit. Für seine bahnbrechende Entwicklung der PolymeraseKettenreaktion ( $\vee$ PCR) erhielt Mullis 1993 den Nobelpreis für Chemie. Diese von ihm entwickelte Technik der DNAAmplifikation hat die molekulare biomedizinische Forschung und Biotechnologie in höchstem Maße gefördert. Neben dem Nobelpreis erhielt Mullis viele bedeutende internationale Auszeichnungen.

\section{Literatur}

Mullis KB (1998) Dancing naked in the mind field. Pantheon Books, New York 